\title{
Supporting Information for Implications of Blanc's Law for Use in Trapped Ion Mobility Spectrometry
}

Cameron N. Naylor ${ }^{1}$, Tobias Reinecke ${ }^{1}$, Mark E. Ridgeway ${ }^{2}$, Melvin A. Park ${ }^{2}$, Brian H. Clowers ${ }^{1^{*}}$

${ }^{1}$ Department of Chemistry, Washington State University, Pullman, WA 99164, United States

${ }^{2}$ Bruker Daltonics Inc., Billerica, MA 01821, United States

*Corresponding Author: Brian H. Clowers (brian.clowers@wsu.edu)

Calibration Equations for Figure 3 and Sup Fig 1: The deviation from Blanc's Law attributed to Figure 4B comes from any error from the DTIMS mobilities that were measured in the respective gas mixtures. The reference mobilities in Figure 4B are not derived from Blanc's Law (although that is one use for Blanc's Law). As such, since there are 5 different gas mixtures, that means there are also 5 different calibration equations for each gas mixture listed as follows:

$100 \% \mathrm{CO}_{2}$

$$
V_{\text {elute }}=-120.011 \frac{1}{K_{0}}+55.61
$$

$75 \% \mathrm{CO}_{2}$

$$
V_{\text {elute }}=-127.314 \frac{1}{K_{0}}+55.42
$$

$50 \% \mathrm{CO}_{2}$

$$
V_{\text {elute }}=-128.26 \frac{1}{K_{0}}+55.12
$$

$20 \% \mathrm{CO}_{2}$

$$
V_{\text {elute }}=-131.46 \frac{1}{K_{0}}+52.32
$$

$100 \% \mathrm{~N}_{2}$

$$
V_{\text {elute }}=-138.46 \frac{1}{K_{0}}+49.077
$$


Table S1: Reduced mobility values of each of the analytes in the respective drift gas measured in a DTIMS. While the neat drift gases have been previously reported, they are used for TIMS calibration and evaluation of Blanc's Law in synthetic air. ${ }^{1}$

\begin{tabular}{|c|c|c|c|c|c|c|c|c|}
\hline & $\begin{array}{l}\mathrm{He} \\
\left(\mathrm{cm}^{2} \mathrm{~V}^{-}\right. \\
\left.{ }^{1} \mathrm{sec}^{-1}\right)^{1}\end{array}$ & $\begin{array}{l}\mathrm{O}_{2} \\
\left(\mathrm{~cm}^{2} \mathrm{~V}^{-}\right. \\
\left.{ }^{1} \mathrm{sec}^{-1}\right)^{1}\end{array}$ & $\begin{array}{l}\operatorname{Ar}\left(\mathrm{cm}^{2} \mathrm{~V}^{-}\right. \\
\left.{ }^{1} \mathrm{sec}^{-1}\right)^{1}\end{array}$ & $\begin{array}{l}\mathrm{N}_{2} \\
\left(\mathrm{~cm}^{2} \mathrm{~V}^{-}\right. \\
\left.{ }^{1} \mathrm{sec}^{-1}\right)^{1}\end{array}$ & $\begin{array}{l}\mathrm{CO}_{2} \\
\left(\mathrm{~cm}^{2} \mathrm{~V}^{-}\right. \\
\left.{ }^{1} \mathrm{sec}^{-1}\right)^{1}\end{array}$ & $\begin{array}{l}\mathrm{N}_{2} \mathrm{O} \\
\left(\mathrm{cm}^{2} \mathrm{~V}^{-}\right. \\
\left.{ }^{1} \mathrm{sec}^{-1}\right)^{1}\end{array}$ & $\begin{array}{l}\text { Compressed } \\
\text { Air }\left(\mathrm{cm}^{2} \mathrm{~V}^{-}\right. \\
\left.{ }^{1} \mathrm{sec}^{-1}\right)\end{array}$ & $\begin{array}{l}\text { Synthetic Air } \\
\left(\mathrm{cm}^{2} \mathrm{~V}^{-1} \mathrm{sec}^{-1}\right)\end{array}$ \\
\hline AAA & $\begin{array}{l}430 \pm \\
008\end{array}$ & $\begin{array}{l}1.306 \pm 0 \\
002\end{array}$ & $\begin{array}{l}1.185 \pm 0 \\
005\end{array}$ & $\begin{array}{l}1.312 \pm 0 \\
.002\end{array}$ & $\begin{array}{l}0.7425 \pm \\
0.0012\end{array}$ & $\begin{array}{l}0.706 \\
\pm 0.006\end{array}$ & $1.304 \pm 0.003$ & $1.296 \pm 0.003$ \\
\hline T3A & $\begin{array}{l}517 \pm \\
47\end{array}$ & $\begin{array}{l}1.407 \pm 0 . \\
002\end{array}$ & $\begin{array}{l}1.261 \pm 0 \\
003\end{array}$ & $\begin{array}{l}1.434 \pm 0 \\
.019\end{array}$ & $\begin{array}{l}0.8639 \pm \\
0.0011\end{array}$ & $\begin{array}{l}0.832 \pm \\
0.010\end{array}$ & $1.425 \pm 0.002$ & $\begin{array}{l}1.4209 \pm 0.00 \\
02\end{array}$ \\
\hline T4A & $\begin{array}{l}424 \pm \\
028\end{array}$ & $\begin{array}{l}1.203 \pm 0 \\
002\end{array}$ & $\begin{array}{l}1.076 \pm 0 \\
002\end{array}$ & & $\begin{array}{l}0.7681 \pm \\
0.0009\end{array}$ & $\begin{array}{l}0.740 \pm \\
0.009\end{array}$ & $1.224 \pm 0.002$ & $\begin{array}{l}1.2208 \pm 0.00 \\
05\end{array}$ \\
\hline T5A & $\begin{array}{l}703 \pm \\
021\end{array}$ & $\begin{array}{l}1.043 \pm 0 \\
002\end{array}$ & $\begin{array}{l}0.932 \pm 0 \\
002\end{array}$ & $\begin{array}{l}1.072 \pm 0 \\
.013\end{array}$ & $\begin{array}{l}0.6872 \pm \\
0.0006\end{array}$ & $\begin{array}{l}0.662 \pm \\
0.008\end{array}$ & $1.065 \pm 0.001$ & $\begin{array}{l}1.0616 \pm 0.00 \\
02\end{array}$ \\
\hline T6A & $\begin{array}{l}3.202 \pm \\
0.016\end{array}$ & $\begin{array}{l}0.924 \pm 0 \\
001\end{array}$ & $\begin{array}{l}0.826 \pm 0 \\
002\end{array}$ & $\begin{array}{l}0.952 \pm 0 \\
.012\end{array}$ & $\begin{array}{l}0.6217 \pm \\
0.0006\end{array}$ & $\begin{array}{l}0.600 \pm \\
0.007\end{array}$ & $0.945 \pm 0.001$ & $\begin{array}{l}0.9423 \pm 0.00 \\
01\end{array}$ \\
\hline T7A & $\begin{array}{l}2.845 \pm \\
0.010\end{array}$ & $\begin{array}{l}0.834 \pm 0 \\
001\end{array}$ & $\begin{array}{l}0.745 \pm 0 \\
001\end{array}$ & $\begin{array}{l}0.861 \pm 0 \\
.010\end{array}$ & $\begin{array}{l}0.5692 \pm \\
0.0006\end{array}$ & $\begin{array}{l}0.550 \pm \\
0.006\end{array}$ & $0.854 \pm 0.001$ & $\begin{array}{l}0.85223 \pm 0.0 \\
0008\end{array}$ \\
\hline T8A & $\begin{array}{l}2.570 \pm \\
0.010\end{array}$ & $\begin{array}{l}0.7638 \pm \\
0.0009\end{array}$ & $\begin{array}{l}0.6823 \pm 0 \\
.0009\end{array}$ & $\begin{array}{l}0.789 \pm 0 \\
.009\end{array}$ & $\begin{array}{l}0.5266 \pm \\
0.0005\end{array}$ & $\begin{array}{l}0.510 \pm \\
0.006\end{array}$ & $0.783 \pm 0.001$ & $\begin{array}{l}0.7810 \pm 0.00 \\
01\end{array}$ \\
\hline T10A & $\begin{array}{l}2.202 \pm \\
0.008\end{array}$ & $\begin{array}{l}0.6653 \pm \\
0.0006\end{array}$ & $\begin{array}{l}0.5942 \pm 0 \\
.0007\end{array}$ & $\begin{array}{l}0.689 \pm 0 \\
.008\end{array}$ & $\begin{array}{l}0.4655 \pm \\
0.0004\end{array}$ & $\begin{array}{l}0.452 \pm \\
0.005\end{array}$ & $0.684 \pm 0.001$ & $\begin{array}{l}0.6821 \pm 0.00 \\
03\end{array}$ \\
\hline T12A & $\begin{array}{l}1.993 \pm \\
0.007\end{array}$ & $\begin{array}{l}0.6077 \pm \\
0.0002\end{array}$ & $\begin{array}{l}0.5425 \pm 0 \\
.0007\end{array}$ & $\begin{array}{l}0.631 \pm 0 \\
.008\end{array}$ & $\begin{array}{l}0.4292 \pm \\
0.0003\end{array}$ & $\begin{array}{l}0.417 \pm \\
0.005\end{array}$ & $0.626 \pm 0.001$ & $\begin{array}{l}0.6243 \pm 0.00 \\
03\end{array}$ \\
\hline
\end{tabular}


Table S2: The elution voltages for all the calibrants used in determining Blanc's Law's application for TIMS calibration. The settings under which these were collected are listed in Table 1.

\begin{tabular}{|c|c|c|c|c|c|c|c|c|}
\hline & \multicolumn{8}{|c|}{ Elution Voltage for Binary Mixtures of nitrogen and $\mathrm{Ar}$ or $\mathrm{CO}_{2}(\mathrm{~V})$} \\
\hline Calibrant & $75 \% \mathrm{Ar}$ & $50 \% \mathrm{Ar}$ & $25 \% \mathrm{Ar}$ & $100 \% \mathrm{~N}_{2}$ & $25 \% \mathrm{CO}_{2}$ & $50 \% \mathrm{CO}_{2}$ & $75 \% \mathrm{CO}_{2}$ & $100 \% \mathrm{CO}_{2}$ \\
\hline T3A & & & $-46.4 \pm 0.6$ & $-47.7 \pm 0.7$ & $-55 \pm 1$ & $-64.0 \pm 0.7$ & $-77.2 \pm 0.4$ & \\
\hline T4A & $-58.8 \pm 0.9$ & $-61 \pm 1$ & $-62.3 \pm 0.6$ & $-63.5 \pm 0.9$ & $-71 \pm 1$ & $-80.6 \pm 0.7$ & $-95.2 \pm 0.6$ & $-100.8 \pm 0.6$ \\
\hline T5A & $-74.7 \pm 0.6$ & $-77.5 \pm 0.9$ & $-79.1 \pm 0.7$ & $-80.2 \pm 0.8$ & $-87 \pm 1$ & $-98.1 \pm 0.9$ & $-113.8 \pm 0.7$ & $-118.7 \pm 0.4$ \\
\hline T6A & $-90.6 \pm 0.6$ & $-94 \pm 1$ & $-95.4 \pm 0.8$ & $-96.6 \pm 0.9$ & $-104 \pm 1$ & $-115.2 \pm 0.9$ & $-131.9 \pm 0.6$ & $-137.6 \pm 0.7$ \\
\hline T7A & $-105.7 \pm 0.7$ & $-109 \pm 1$ & $\begin{array}{l}- \\
110.9 \pm 0 . \\
8\end{array}$ & $\begin{array}{l}- \\
112.1 \pm 0.9\end{array}$ & $-120 \pm 2$ & $-131.6 \pm 1.1$ & $-149.7 \pm 0.8$ & $-155.0 \pm 0.8$ \\
\hline T8A & $-120.2 \pm 0.8$ & $-124 \pm 1$ & $\begin{array}{l}- \\
125.7 \pm 0 \\
7\end{array}$ & $-127 \pm 1$ & $-135 \pm 2$ & $-148 \pm 1$ & $-166.7 \pm 0.8$ & $-172.4 \pm 0.8$ \\
\hline T10A & $-146.9 \pm 0.8$ & $-151 \pm 1$ & $\begin{array}{l}- \\
152.7 \pm 0 . \\
8\end{array}$ & $-154 \pm 1$ & $-162 \pm 2$ & $-176 \pm 1$ & & \\
\hline T12A & $-169.2 \pm 0.9$ & $-173 \pm 2$ & $-175 \pm 1$ & $-176 \pm 1$ & & & & \\
\hline TM322 & $-51.0 \pm 0.8$ & $-53.0 \pm 1$ & $-54.6 \pm 0.6$ & $-55.7 \pm 0.9$ & $-63 \pm 1$ & $-73.6 \pm 0.8$ & $-88.3 \pm 0.6$ & $-94.2 \pm 0.5$ \\
\hline TM622 & & & & $-92.8 \pm 0.9$ & $-103 \pm 1$ & $-115.9 \pm 0.9$ & $-134.9 \pm 0.7$ & $-142.2 \pm 0.7$ \\
\hline TM922 & & & & $-123 \pm 1$ & $-132 \pm 2$ & $-144.4 \pm 0.9$ & $-164.7 \pm 0.9$ & $-171.1 \pm 0.9$ \\
\hline 10TMA & & & & $-59.7 \pm 0.7$ & $-68 \pm 1$ & $-79.1 \pm 0.9$ & $-94.5 \pm 0.9$ & $-99.2 \pm 0.3$ \\
\hline 12TMA & & & & $-68.6 \pm 0.8$ & $-77 \pm 1$ & $-88.4 \pm 0.8$ & $-104.7 \pm 0.4$ & $-111.2 \pm 0.8$ \\
\hline 14TMA & & & & $-76.5 \pm 0.9$ & $-86 \pm 1$ & $-97 \pm 1$ & $-114.3 \pm 0.7$ & $-121 \pm 1$ \\
\hline 18TMA & & & & $-89.8 \pm 0.7$ & $-99 \pm 1$ & $-111.5 \pm 0.9$ & $-129.2 \pm 0.6$ & $-134 \pm 1$ \\
\hline
\end{tabular}



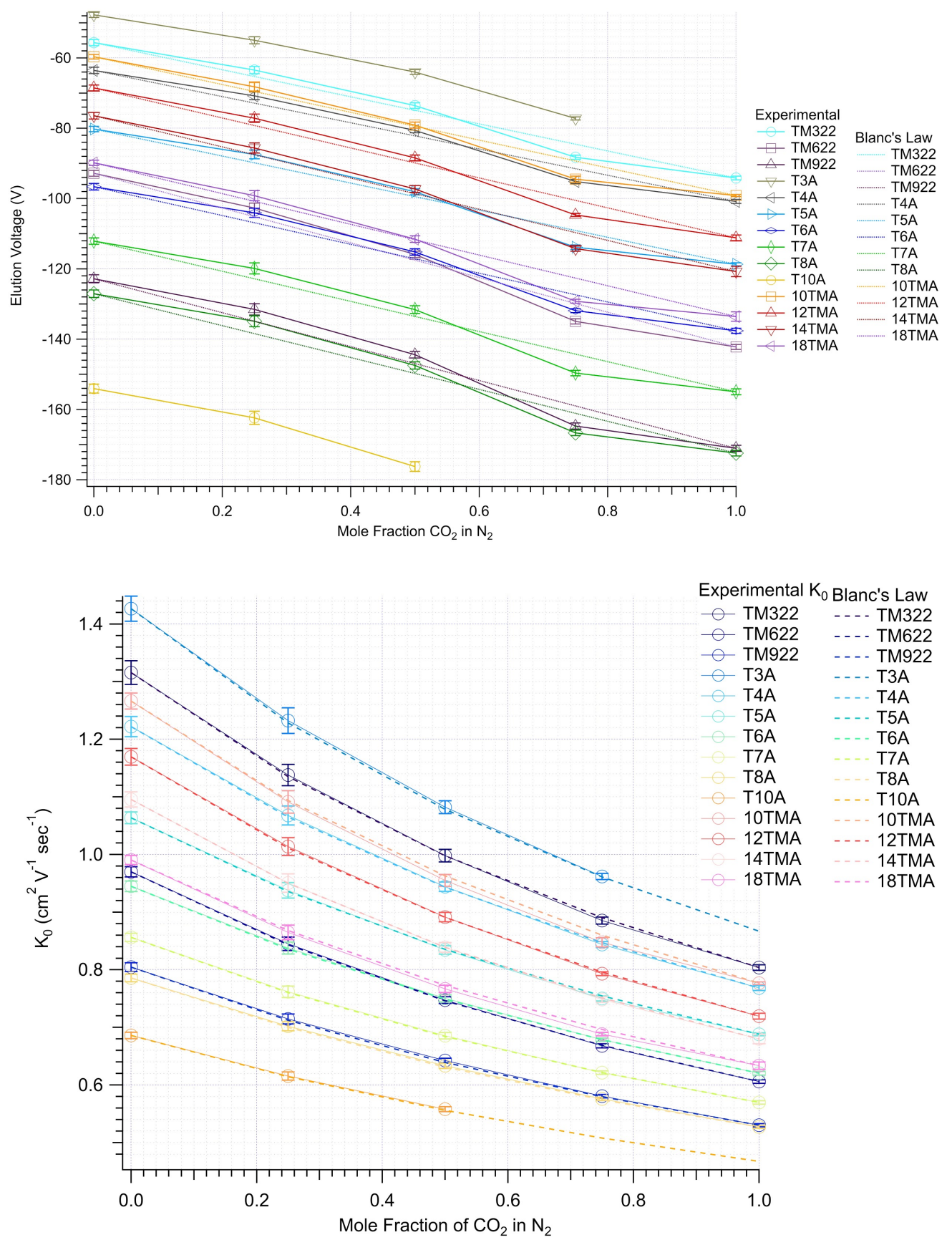

Figure S1: Mixtures of $\mathrm{N}_{2}$ and $\mathrm{CO}_{2}$ in the TIMS and the deviation from Blanc's Law which is corrected for when the TIMS is calibrated. This contains all the species for the calibration and thus is an extension of Figure 4. 

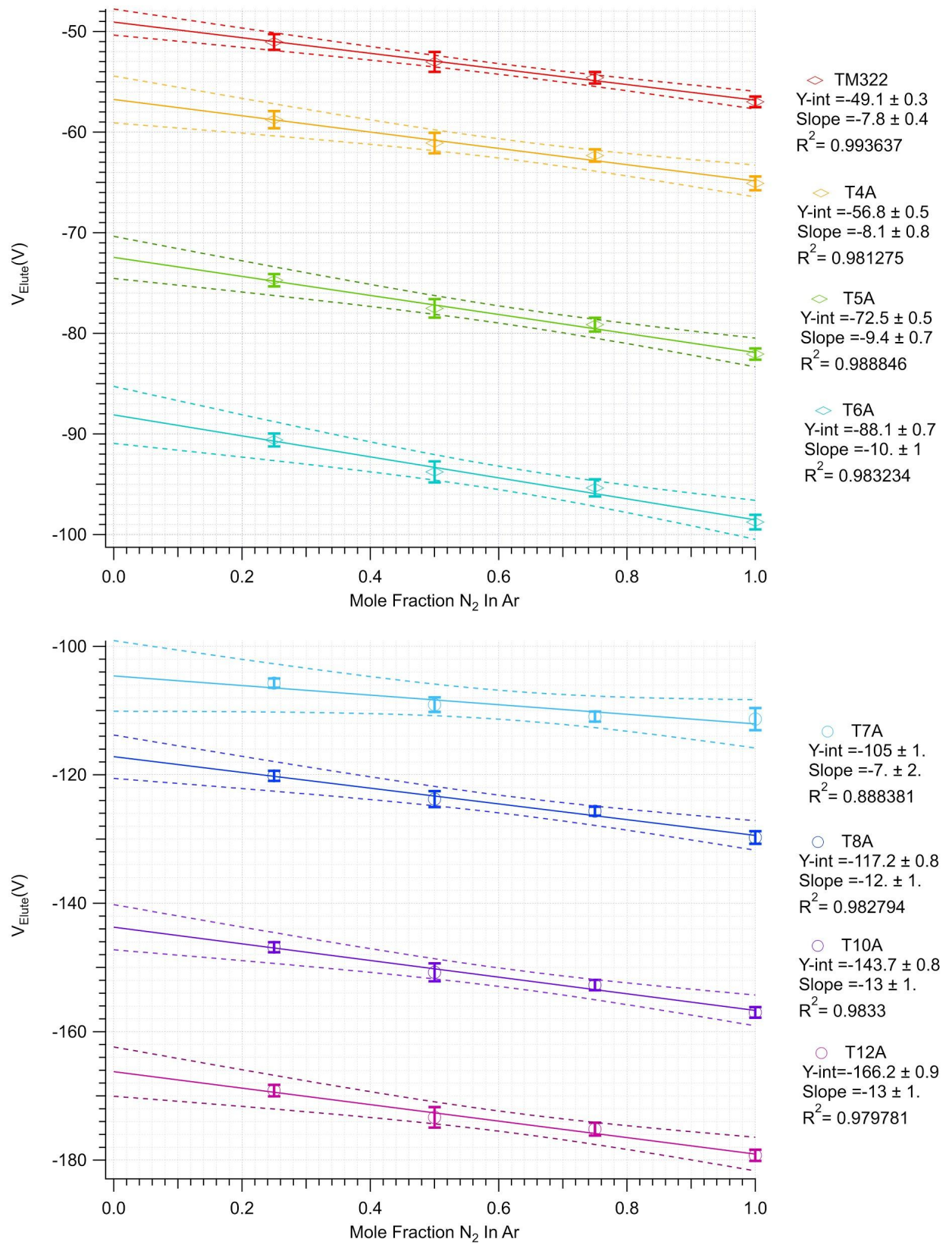

Figure S2: Mixtures of $\mathrm{Ar}$ and $\mathrm{N}_{2}$ with the elution voltages measured within the TIMS. Analytes are not able to be analyzed in pure argon due to the difference in settings required for analysis, so a linear fit is applied in accordance with Blanc's Law. As the mixture becomes increasingly more argon (left side of graph), the elution voltage increases indicating analytes eluting later than when they would elute in pure nitrogen. 

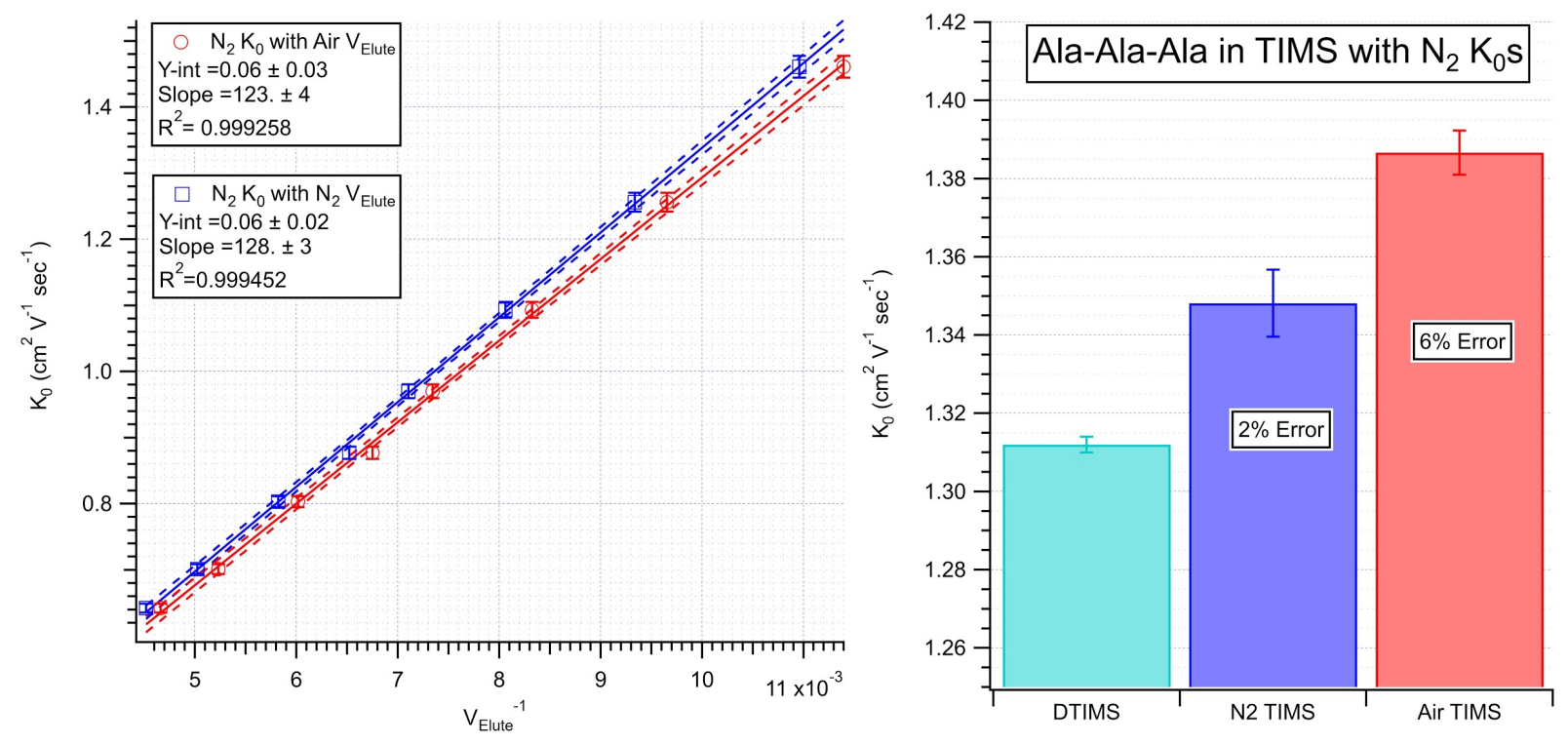

Figure S3: When The $\mathrm{K}_{0} \mathrm{~S}$ of $\mathrm{N}_{2}$ are used for the TIMS calibration of the TXA salts and the subsequent error when those calibration plots are used to find the mobility of AlaAla-Ala in the TIMS 

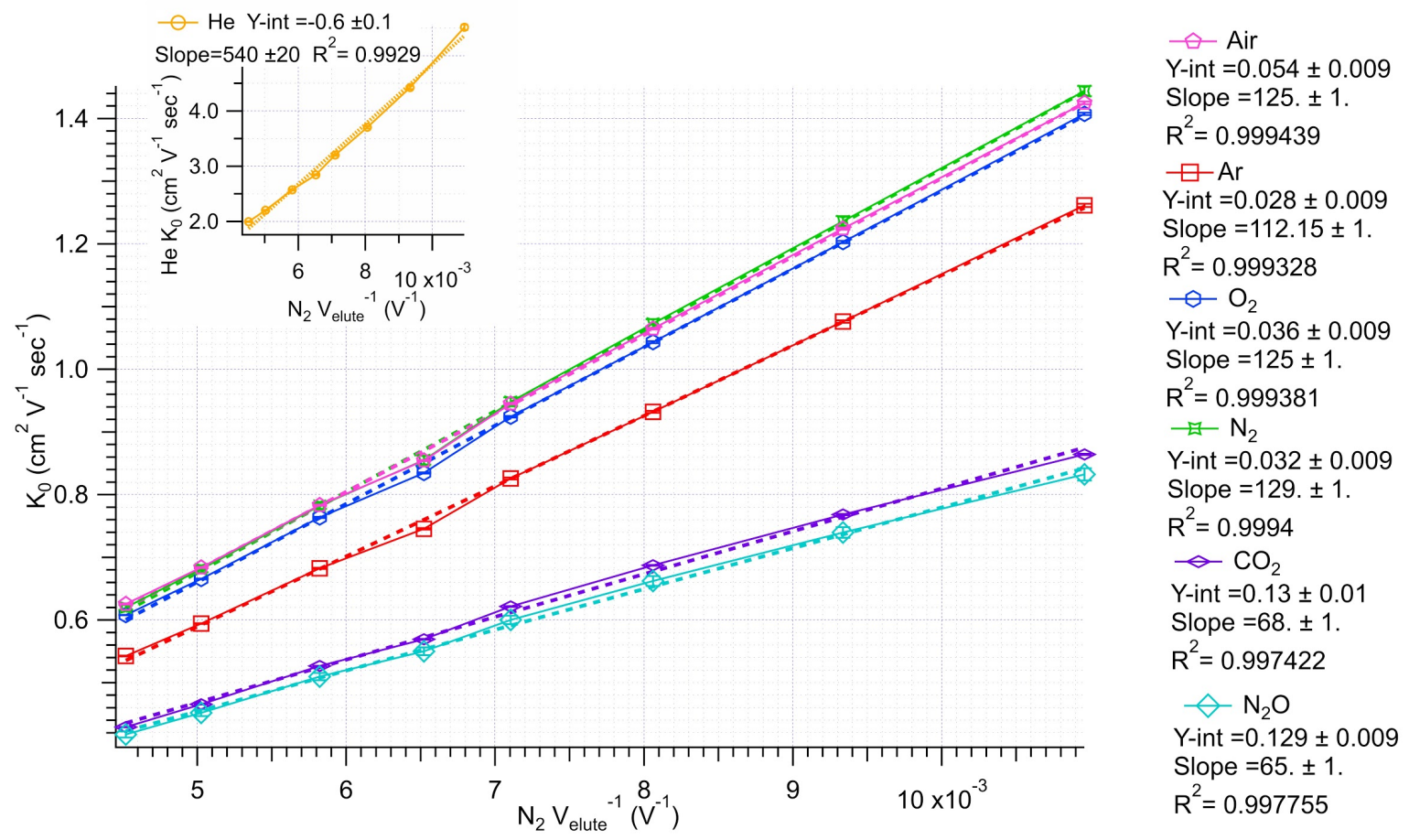

Figure S4: When the TIMS is filled with nitrogen for TIMS analysis, the reference mobilities of TXA salts in different gases obtained from a DTIMS are used to create the calibration. Gases that are very similar in mobility to nitrogen (i.e. air, $\mathrm{Ar}, \mathrm{O}_{2}$ ) had a linear calibration curve. However, the more that the identity of the drift gas differs from nitrogen (i.e. $\mathrm{He}, \mathrm{CO}_{2}, \mathrm{~N}_{2} \mathrm{O}$ ), the more error entered into the calibration curve. The resulting differences in calibration curves for an external standard (Ala-ala-ala) in Figure 5 are up to $11 \%$ depending on the gas the reference mobilities were measured in for calibration in nitrogen. 


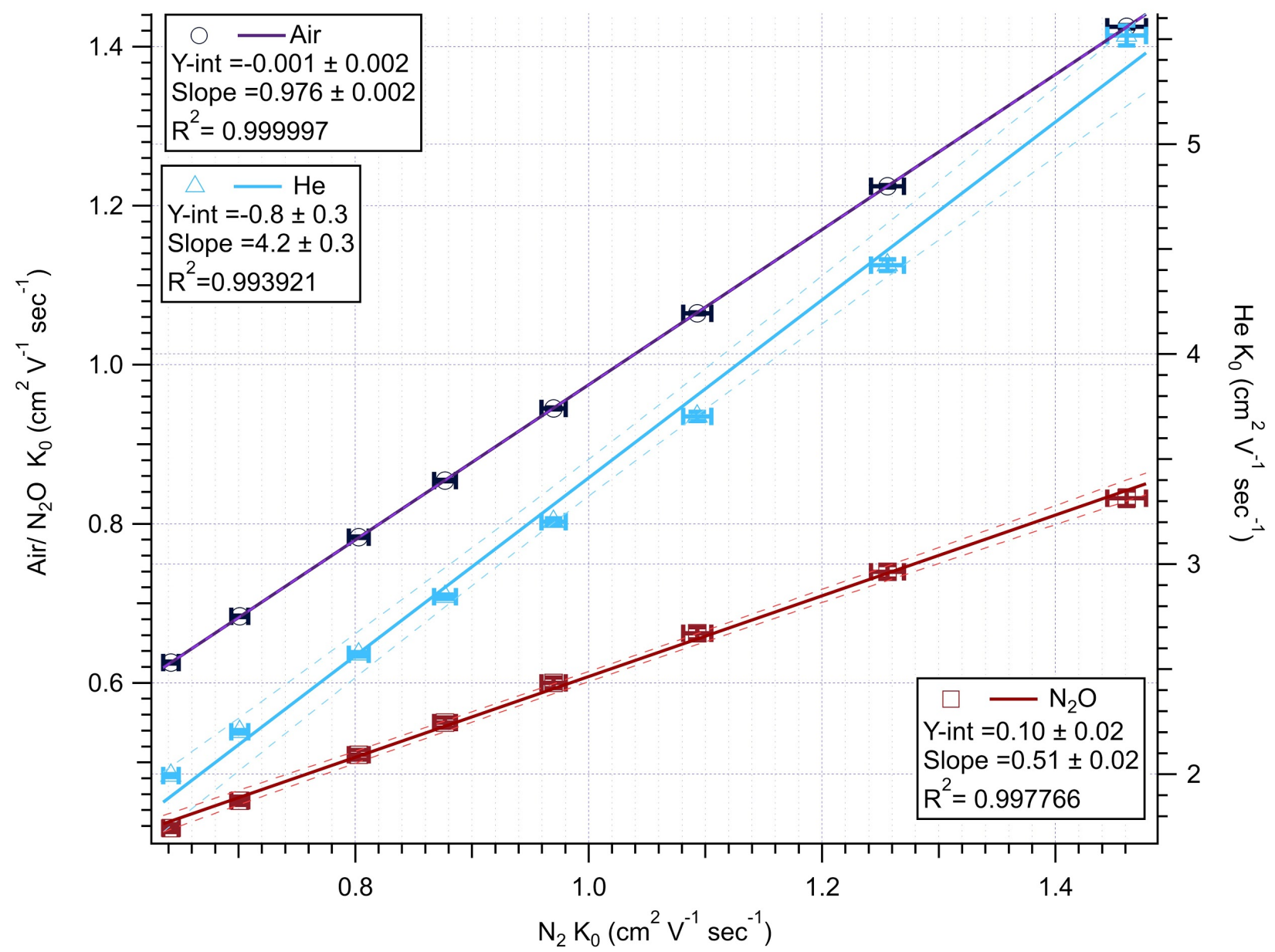

Figure S5: The relationship between nitrogen and other mobilities. For nitrogen and air, the relationship is linear, due to the similarities in mobility and polarizability. However, if a drastically different gas is used such as helium or $\mathrm{N}_{2} \mathrm{O}$, the relationship is no longer linear (i.e. there is a distinct curve in the graph when compared to the line of best fit, even though the $R^{2}>0.99$ ). This relationship is reflected in the TIMS calibration if gases drastically different than what is in the TIMS is used for TIMS calibration. 


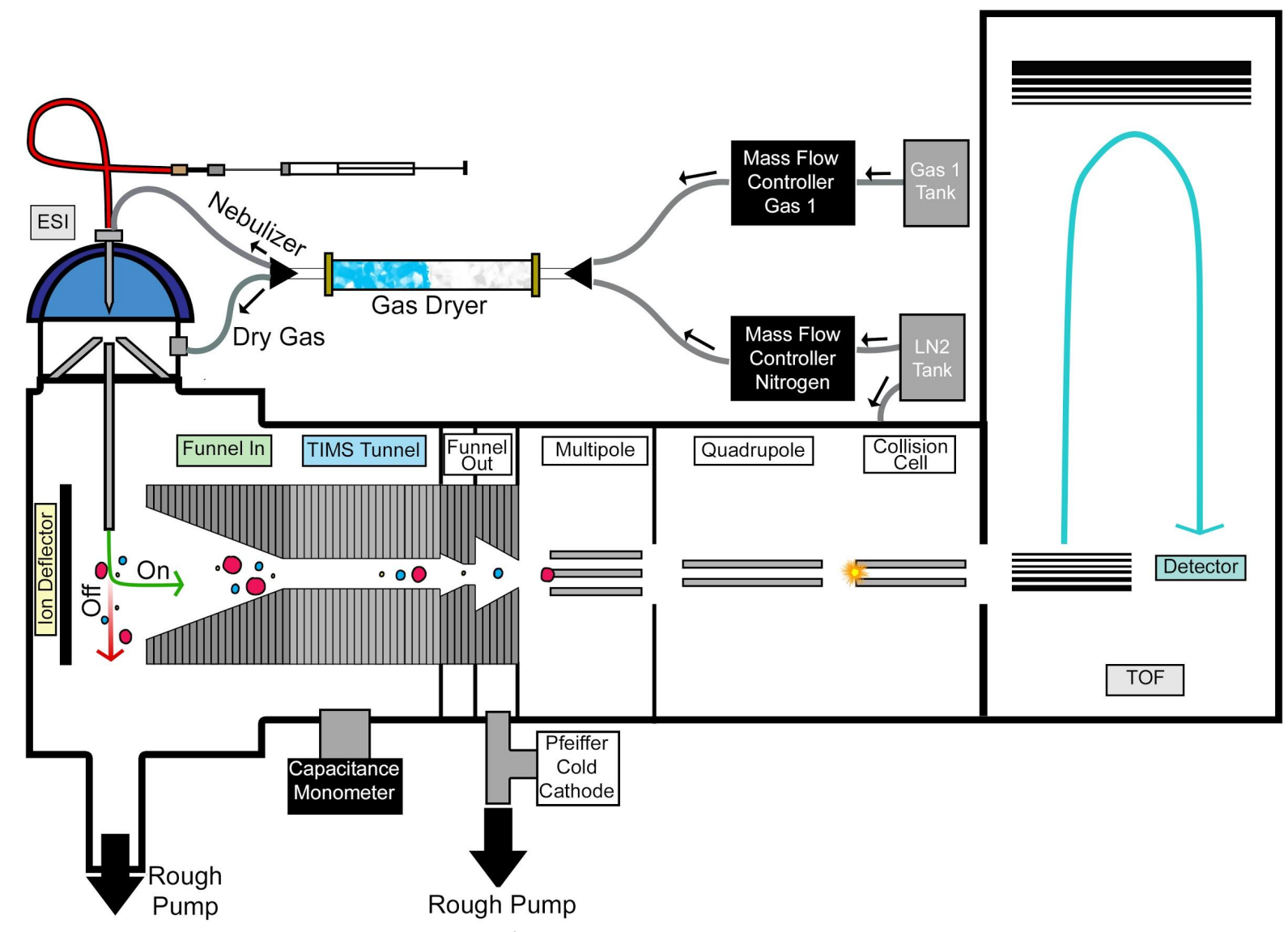

Figure S6: A schematic of how the mixed drift gases were introduced into the TIMS. Due to the flow controller in the microTOF being hard-coded to nitrogen specifically, the gas generated from the liquid nitrogen tank was split with half going to the TOF/collision cell inlet and the other half was passed to a Cole Parmer Flow Controller set for nitrogen. The line from this flow controller was merged with an identical flow controller set for either $\mathrm{Ar}$ or $\mathrm{CO}_{2}$ before passing through a gas dryer and being introduced to the ESI nebulizer and gas inlet for the TIMS in the microTOF Apollo II source.

\section{References}

(1) Naylor, C. N.; Reinecke, T.; Clowers, B. H. Assessing the Impact of Drift Gas Polarizability in Polyatomic Ion Mobility Experiments. Anal. Chem. 2020, 92 (6), 4226-4234. 